\title{
PECULIARITIES OF LEGAL RESPONSIBILITY FOR OFFENSES IN THE FIELD OF CLINICAL TRIALS OF MEDICINES
}

D0I: 10.36740/WLek202012222

\author{
Viacheslav I. Borysov ${ }^{1}$, Olena I. Antoniuk ${ }^{2}$, Oleksandr 0. Pashchenko ${ }^{1}$ \\ 'ACADEMICIAN STASHIS SCIENTIFIC RESEARCH INSTITUTE FOR THE STUDY OF CRIME PROBLEMS NATIONAL ACADEMY OF LAW SCIENCES OF UKRAINE, \\ KHARKIV, UKRAINE \\ ${ }^{2}$ SUPREME COURT, KYIV, UKRAINE
}

\begin{abstract}
The aim: Is to determine the features of legal liability for violations in the field of clinical trials of medicine remedies and justification of proposals to strengthen the protection of participants' interests in clinical trials through the use of various types of such liability.

Materials and methods: The authors used the decisions of the European Court of Human Rights (ECHR) on medical research, international and national regulations, and publications of scholars in the field of medical law. The research was carried out on the basis of a systematic approach using the methods of dialectical and formal logic, general scientific and special legal research methods.

Conclusions: In order to properly ensure the legal protection of public interests, as well as the rights and interests of research subjects and other entities involved in their implementation, the authors argue the need to use different types of legal liability.
\end{abstract}

KEY WORDS: researcher, clinical trial, research subject, offense, liability

Wiad Lek. 2020;73(12 p. II):2833-2839

\section{INTRODUCTION}

The relevance of clinical trials has increased during pandemic, which necessitated the development of vaccines and their clinical trials as quickly as possible. At the same time, there are many reports of side effects of such medicines, which are observed in different countries. It raises the issue of improving the protection of the rights and interests of study subjects, including through the institution of legal liability. The essence of clinical trials is associated with risks for persons involved in clinical trial, as such trials are an innovative research activity to verify (confirm) the effectiveness of unregistered medicine remedies, which requires regulatory effective protection of interests of various subjects involved in clinical trial, as well as public interests, using various types of legal liability.

The legal regulation of legal liability and sanctions for offenses in the field of clinical trials should, above all, take into account the nature of clinical trial, the procedure for its conduct and the legal status of subjects and various participants in clinical trial.

The shortcomings of legal regulation of legal liability, in particular criminal law, reduce the effectiveness of legal protection of public and private interests in this area, which, given the increased risks of harm, requires special attention to basis for such liability and appropriate sanctions.

Not enough attention is paid to these issues in the scientific literature. In view of this, the issues of legal liability for offenses in the field of clinical trials require comprehensive doctrinal elaboration.

\section{THE AIM}

The purpose of the study is to determine the features of legal liability for violations in the field of clinical trials of medicines and justification of proposals to strengthen the protection of participants' interests in clinical trials through the use of various types of such liability.

\section{MATERIALS AND METHODS}

To achieve the objectives of the study, statistics in terms of quantity of clinical trials in different countries were analyzed. The study also used statistical data on initiation of criminal proceedings for offenses related to clinical trials in Ukraine.

The decisions of the European Court of Human Rights (hereinafter - the ECHR) in cases concerning the use of unregistered methods of treatment are analyzed. In addition, international and national regulations have been studied, which define the general provisions of legal liability in the field of clinical trials, as well as establish sanctions for offenses during their conduct.

The relevance of this study was established by studying and analyzing the publications of foreign and domestic researchers on legal liability for offenses in the field of clinical trials. 
The methods of theoretical analysis and synthesis were used in the study of the content of legal norms and concepts contained in international and national regulations on legal liability in the field of clinical trials. Some issues required an application of the method of systematic analysis, in particular, during systematization of different types of offenses and identification of the ratio of different types of legal liability for them.

Formal legal analysis of international and national law was used to study the differences in the application of criminal liability for various offenses that may be committed during clinical trials, and formulate proposals to improve the legal regulation of liability for such offenses in accordance with their public danger and harm. The comparative legal method was used in the analysis of legal consequences regulation for harm to legitimate interests in terms of justified risk to achieve a significant socially useful goal.

The formal-logical (to clarify the characteristics of criminal liability for involvement in clinical trial of the subject with a violation of procedure for obtaining informed consent), functional (in establishing the effectiveness of certain types of legal liability for violation during conducting such tests) methods was also used along with some others.

\section{REVIEW AND DISCUSSION}

In the European Community, approximately 4,000 authorizations for clinical trials are issued each year with an average of two Member States involved in each trial. Allmost $61 \%$ of clinical trials are sponsored by the pharmaceutical industry and 39\% - by non-profit sponsors [1].

The leader among European countries in the number of registered clinical trials is Germany (24.22\%), the United Kingdom is in the second place $(22.83 \%)$, in the third place there is France (19.74\%). Ukraine ranks the 23rd in this list of European countries, having $2.57 \%$ of the total number of clinical trials registered in Europe. In 2018, 395 clinical trials were registered in Ukraine, in 2019 - there were 391 trials. For comparison: in Germany in 2018, 3116 tests were registered, in 2019 - 2900 ones [2].

One of the principles set out in the Integrated Supplement to ICH E6 (R1) "Guidelines for Good Clinical Practice E6 (R2)" of 9 November 2016, an international ethical and scientific standard for the design and conduct of clinical trials involving human beings as a subject, is the prevalence of the rights, security and well-being of the subject of research over the interests of science and society (paragraph 2.3.) [3]. Adherence to this standard is a guarantee to society that the rights, safety and well-being of the research subjects will be protected, and the test results will be reliable, which is at the same time necessary to ensure the public interest in health care.

An example of resolving a dispute between the state and a patient over the use of an experimental medicinal drug based on balancing private and public interests is the case of Christosov and Others v. Bulgaria, heard by the European Court of Human Rights (ECHR). In this case the reason for the complaint was not inadequate treatment itself but the denial of access to a life-saving treatment, the safety and effectiveness of which were still in doubt. The applicants' interest was defined as "the freedom to choose untried treatment as a means of extreme necessity, which may entail risks but is considered by the applicants and their physicians as appropriate in their situation, in order to save their own lives". The compensatory public interest consisted of three parts: 1 ) to protect patients from the risks of unauthorized treatment; 2) make it impossible to circumvent the regulatory framework governing the provision of illicit medicinal drugs; 3 ) ensure that the development of new medicinal drugs is not jeopardized, for example, by reducing patient participation in clinical trials. The ECHR has noted that health policy issues usually lie within the discretion of States. Despite the clear tendency in states to authorize the use of illicit medicines, there is no general agreement on the specific way to regulate neither this issue, nor the established legislative principles in this regard. The ECHR concluded that the balance achieved in national law, whether that balance could be fairer, did not go beyond the discretion afforded to the State. The Court considered the fact that Bulgaria has regulations governing access to illicit medicines in cases where standard treatments are insufficient, and the State (Bulgaria) has the right to deny access to a life-saving treatment, the safety and effectiveness of which are still in doubt [4, p. 56-57].

In the cases of "A.M. and A. K. v. Hungary" The ECHR, in its Decision of 4 April 2017, took into account the data of clinical trials, which showed negative results in medicines ' application for which the applicants tried to obtain an individual permit from the state [5].

Guarantees of observance of inalienable natural rights of the research subject are laid down as in the order of carrying out clinical researches (creation of independent ethical committees for protection and defend of the rights and safety of research subjects, obligation to inform the sponsor and regulatory body of all undesirable phenomena during testing, development of standard operating procedures indicating safety measures, continuous monitoring of testing, suspension or termination of testing in case of a certain level of threats), which is regulated by international ethical and scientific standards, as well as national legislation and legal liability for violation of this procedure, laid down at the level of national legislation. Since it is a question of protection of such personal non-property rights as life and health of the research subject, it is, first, provided by measures of criminal responsibility.

Also, Proper clinical practice (paragraph 2.7) defines the principle of responsibility for medical care provided to the subject of the study, as well as medical decisions. In this case, the researcher is responsible for: proper clinical research (paragraphs 1.34, 4.1.1); all medical decisions made in relation to the subject of the study within the test (4.3.1.); accounting of investigational medicinal product in the research center (paragraph 4.6.1.). The sponsor is responsible for the proper organization of clinical trial (paragraph 1.53), for the researcher's choice (paragraph 5.6.1.), as well as for the quality and completeness of the 
data obtained as trial (paragraph 5.2.1). The sponsor's standard procedures should consider the reimbursement of the cost of treatment of clinical trial participant in the event of harm to health in connection with the study procedure in accordance with regulatory requirements (paragraph 5.8.2).

This corresponds to paragraph 15 of the Nuremberg Code of 1947 [6], according to which the physician is always responsible for the subjects of the study, and the subject of the study is never responsible, despite the latter's consent to participate in the study.

Harmonization of Clinical Trials procedure in Ukraine to international requirements, compliance with the GCP standard is a guarantee that the rights of subjects - patients and healthy volunteers are protected, confidentiality is maintained, and the data obtained during the study are reliable information [7, p. 7].

Art. 76 of Regulation (EU) № 536/2014 [8] provides that Member States are required to provide for compensation systems for any damage caused to the subject by participation in clinical trial conducted on their territory in the form of insurance, guarantees or similar measures equivalent in nature and degree of risk. Under Art. 94 of this Regulation, Member States shall lay down the rules on penalties applicable to infringements of this Regulation and shall take all measures necessary to ensure that they are implemented. Imposed punishments must be effective, proportionate and dissuasive. Under Art. 95 of the Regulation, it does not limit national and union law in the civil and criminal liability of the sponsor and the researcher. In this case, if required by applicable regulations, the sponsor must provide insurance or guarantee legal and financial support to the researcher (organization) in case of claims related to the study, except for those claims that arose as a result of intent or carelessness (clause 5.8.1).

These requirements comply with paragraph 14 of Part 2 of the European Charter of Patients' Rights [9], according to which everyone has the right to receive adequate compensation within a reasonably short period of time in the event of physical or moral and psychological harm.

Compensation for the damage caused to the subjects of the study is provided by insurance (mainly - the sponsor's liability for damage caused in connection with participation in the trial, and in Ukraine - life and health insurance of the subject). In this case, the subject of the study is the beneficiary of the insurance contract concluded by the sponsor.

Damage caused during a clinical trial by a sponsor, research center, researcher is reimbursed in accordance with the rules of civil law, as well as the provisions concluded between these parties to the contract.

The sponsor of a clinical trial has the right to use the civil liability specified in the contract for violation of clinical trials' procedure by an executor for conducting clinical trials. The subject of the study may use such methods of civil protection as compensation for property and moral damage caused by the violation of his rights. The latter may apply disciplinary measures to a physician as an employee of the hospital.
It should be noted that in Ukraine, public law protection of the rights of research subjects is provided mainly through criminal liability (Articles 137, 139-142, 145, 321-2 of the Criminal Code of Ukraine [10], (hereinafter - the Criminal Code of Ukraine).

The Code of Administrative Offenses of Ukraine [11] does not provide for administrative liability for violations in the field of clinical trials. Only Article 44-2 of this Code stipulates liability for violation of restrictions imposed on medical and pharmaceutical workers in the course of their professional activities.

Such restrictions are normatively defined in the Article 78-1 of the Law of Ukraine "Fundamentals of the Legislation of Ukraine on Health Care" [12], among which, in particular, the prohibition to receive from business entities engaged in the production and (or sale) of medicines, products medical purposes, their representatives an improper benefit.

It should be noted that the ban on receiving from business entities engaged in the production and (or) sale of medicines, medical devices, their representatives any samples of medicines, medical devices for use in professional activities does not apply to cases related to conducting clinical trials of medicinal products or clinical trials of medical devices in accordance with contracts.

Analysis of violations that may occur during clinical trials and lead to the application of criminal liability shows their diversity. In view of this, the study of criminal law protection of rights and legally protected interests in the field of clinical trials should be carried out comprehensively and taking into account the nature of clinical trials and the legal status of persons involved: researchers, sponsors, contract research organizations, management organizations research centers, research coordinators, research subjects, etc.

Based on the analysis of criminal law on liability for offenses in the field of clinical trials, the latter can be divided into the following groups:

1. Offenses against life and health.

As it stated in paragraph 11 of Regulation (EC) №536 / 2014 , the risk to the safety of the subject in clinical trial has mainly two sources: the investigational medicinal product and the intervention. Many clinical trials, however, carry only minimal additional risk to the safety of the subject compared to normal clinical practice.

However, the threat to human rights to life and health, as well as the actual harm, may result from: being involved in a clinical trial in violation of the informed consent procedure; violation of the trial protocol for the use of investigational medicinal product, failure to provide or untimely provision of medical care to the subject of the study.

Normative regulation in Ukrainian legislation of criminal liability for damage caused as a result of involvement in clinical trial of a research subject in violation of the procedure for obtaining informed consent (Article 141 of the Criminal Code of Ukraine) has been criticized in the scientific literature. Among the shortcomings of this article: 1) the content of Article 141 of this Code does not correspond to its title, violation of patient rights is a much 
broader concept than violation of the rules of clinical trials of medicines, and covers a number of provisions defined in Articles 139,140,142,145 of the Criminal Code; 2) the victim of clinical trials of medicinal products without their own written (informed) consent, or written (informed) consent of the representative, may be only an adult person who has been subjected to such trials. The other two categories of victims should be recognized as such regardless of the written consent of them and their representatives, which is unreasonable and contrary to the Convention on Human Rights and Biomedicine, as well as the Procedure for clinical trials of medicines that allow clinical trials and the involvement of minors; 3 ) criminal liability is provided for conducting clinical trials without written informed consent, but it may, under certain conditions, be provided orally; 4) there is no consideration that informed consent can be given on certain grounds not only by the legal representative, but also by a close relative [13, p. 5, 67-68,100-103].

When deciding on the qualification of actions that violate the rights to life and health of the subject, it should be borne in mind that such protection is ensured by several components of the crime, between which there may be competition.

Thus, there is a separate liability for murder, infliction of bodily injuries of varying severity, as well as for failure to provide to the patient a medical professional who is obliged, according to established rules, to provide such assistance without apropriate reason, if he/she knows that it may have serious consequences for the patient, non-performance or improper performance of their professional duties by a medical or pharmaceutical worker due to negligent or dishonest treatment, if this caused serious consequences for the patient, conducting clinical trials of medicines without the written consent of a patient or his/ her legal representative, if these actions caused the death of a patient or other serious consequences, illegal conduct of medical-biological, psychological or other experiments on a person, if it endangered their life or health, intentional illegal disclosure of medical secrets, if such an act caused serious consequences.

It should be borne in mind that in the presence of special corpus delicti in the field of clinical trials, they should be used in the classification of crimes in this area.

It is also important to note that clinical trials are research and innovation activities in the field of medicine, not medical care. Its essence is to study an unregistered drug to establish or confirm its effectiveness and safety. Therefore, causing harm during such tests should be carried out according to the rules of justified risk (act related to risk - Article 42 of the Criminal Code of Ukraine [10], Article 27 of the Criminal Code of the Republic of Poland [14]).

The Ukrainian legislator establishes that an act (action or omission) that has harmed law enforcement interests is not a crime if this act was committed in conditions of justified risk to achieve a significant socially useful goal. In this case, such a goal can be determined by the presence of real or potential danger, the need to obtain new knowledge (at research risk) $[15$, p. 168, 169],
Obviously, the study of an unregistered medicinal product to establish or confirm its effectiveness and safety is fully consistent with the purpose set by law. But in addition to the goal, it is necessary to comply with certain other conditions, namely: 1) this goal could not be achieved in this situation by action (inaction), not associated with risk; 2 ) the person who took the risk reasonably expected that the measures taken by him/her were sufficient to prevent harm to law enforcement interests. It seems that the first condition for the study of an unregistered medicine is performed a priori, because this study is carried out precisely to prove the safety of a new medicine, to learn about anything else (other than testing) is not possible at all. The second condition must be assessed on a case-by-case basis, depending on availability and effectiveness of the means chosen by the physicians conducting the tests to prevent harm to the subject. It should be recalled that the subject' human rights differ from the patient's human rights in the provision of medical care. Both groups of rights belong to human rights in the field of health care [16, p. 2470]. It is important for the assessment of the object and the objective side of a certain crime in the qualification of the actions of subjects of clinical trials, if the conditions of justified risk are not met.

It should also be noted that Chapter 3 of the General Part of the Criminal Code of the Republic of Poland "Exemption from Criminal Liability" contains Art. 27, according to which a person who acts, in particular, for the purpose of conducting a cognitive or medical experiment, does not commit a crime, if the expected benefit has significant cognitive, medical significance, and the expected achievements, expediency and method of experiment are justified in the light of modern knowledge. The experiment is not allowed without the consent of the participant, where it is conducted, duly informed about the expected benefits and negative consequences that threaten him/her, and the likelihood of their occurrence, as well as the ability to terminate the experiment at any stage [14, p. 13]).

As you can see, The Polish legislator establishes the same conditions for the legality of clinical trials of medicinal products as the Ukrainian one: the goal generally coincides, but the fact that the Criminal Code of Ukraine states that "the reasonable calculation of measures taken to prevent harm" the method of experiment was justified "in the light of modern knowledge."

\section{Offenses against public health.}

Thus, certain violations committed during clinical trials may not pose a threat to the subject's life or health (which is inherent in the offense of the first group), but may pose a serious threat to public health, for example, in the case of falsification study data, in particular, by hiding the negative effects of the study medicine on the human body.

It should be agreed that not any, even intentional, violation of the established procedure for preclinical studies, clinical trials and state registration of medicines is socially dangerous and indicates falsification and impossibility of further state registration of the drug and its admission to use. For example, if the date or signature of the authorized 
person was not affixed to any document during the clinical trial, it is a violation of the relevant procedure, but it would not be rational to prosecute the perpetrator [17]

Establishing the same criminal liability for violating the order of clinical trials with varying degrees of threat to public safety provokes reasonable criticism from the pharmaceutical industry. Thus, the European Business Association notes that the prediction for procedural violations during a clinical trial of criminal liability instead of administrative pressure on physicians, pharmaceutical companies, specialists in the examination of registration materials, as well as materials of preclinical studies and clinical trials, the quality of which depends on availability medicines and the country's image in the field of science-intensive clinical research projects [18].

For example, the Criminal Code of Ukraine (Article 3212) provides for criminal liability for violation of procedure of conducting a clinical trial.

The main feature of this paper is that criminal liability under part one of this article is provided even in the absence of specific harm caused by phisician-researcher or other participant in clinical trials to the state, hospital, subject, sponsor, etc. or its real threat, although for such actions a rather severe punishment is applied - imprisonment for a term of three to five years with deprivation of the right to hold certain positions or engage in certain activities for a term of one to three years. That is, for any violation of clinical trials' order, even those that do not endanger the life, health, safety of the subjects of study, do not threaten the integrity and reliability of the study data, there is no alternative to imprisonment. In addition, this paper does not determine independently the list of criminally punishable acts but refers to the relevant regulations.

It should be emphasized that criminal liability is the most severe type of legal liability of medical workers for offenses committed by them in the course of their professional activities. The Ukrainian legislator has unjustifiably refused to protect private and public interests in the field of clinical trials by establishing of administrative liability, although its introduction could help differentiate legal liability depending on the nature of the clinical trial violation and the negative consequences of such a violation.

There is no criminal liability for unintentional violation of the clinical trial procedure, except for conducting clinical trials without obtaining the informed consent of the subject, if these actions resulted in the death of a patient or other serious consequence. For such actions, a separate criminal liability is provided by Article 141 of the Criminal Code of Ukraine, which does not provide for the intent of such actions. This article aims to ensure the protection of the right to a conscious decision to participate in a clinical trial of a viable person.

According to official statistics, under this article in 2019, 26 criminal proceedings were registered, of which 6 were closed and 2 were sent to court. At the same time, in the first 5 months of 2020, 13 proceedings were registered, none of which has yet been closed or sent to court. Sentences under this article were not published in the public domain. For comparison - for conducting a clinical trial without the informed consent of the patient, which led to serious consequences, in 2019 and 2020, one criminal case was registered [19].

Under Art. 141 of the Criminal Code of Ukraine for the period from 2013 to August 2020, only 6 criminal proceedings were registered but no person was prosecuted [20].

Based on the analysis of the Unified State Register of Judgments, it should be noted that Ukrainian courts have not prosecuted persons under Article 141 and Article 321-2 of the Criminal Code of Ukraine.

This also confirms the ineffectiveness of the legislator's use of criminal liability for these actions, which in practice does not lead to the application of criminal liability by the court to violators.

1. Offenses in the field of official activity.

Such violations may be committed by officials of health care facilities.

For example, concluding a contract for a clinical trial by a head of health care facility may be, under certain circumstances, qualified by law enforcement agencies as an abuse by an official of his/her powers for the purpose of perception of improper advantage for theirselves or others, use against the interests of legal entity, if this has caused significant damage to the interests of health care institution protected by law, or in addition to state interests, if the relevant hospital belongs to state ownership.

The criminal qualification of such actions of health care institution' head is relevant for those states in which it is allowed to conclude along with the contract for clinical trial between the trial client and the hospital, separate agreements with researchers, co-researchers, research coordinators, which they perform in their free time, work in the hospital. The first contracts usually indicate the consent of the hospital to enter into a separate contract with these persons, who are also employees of the hospital. In case of coincidence of functions of hospital and other executors (researchers, co-researchers, coordinators of test) in contracts, there is a situation when the researcher will receive means for the actions which he carries out in the working hours and which are at the same time a contract of the test customer and hospital. This situation can be considered by law enforcement agencies as a result of a deliberate conspiracy of the head of the hospital and staff to reduce the flow of funds to the hospital budget for the personal enrichment of these persons.

The qualification of such actions of officials is related to rule application on the procedure for registration of legal relations of participants in clinical trials, which have differences in different countries.

1. Offenses in the field of economic activity (which includes conducting clinical trials), regarding taxation.

Because clinical trials of medicinal products are paid for, entities that receive funding for services and work performed as part of clinical trials must declare them and pay income taxes on such activities.

The peculiarities of taxation of profits received from non-resident customers for services (works) should be con- 
sidered while determining the tax liabilities of a participant in clinical trials, as well as correctly assess the nature of those services that were provided to such entities tax regime.

Persons involved in clinical trials may provide services for certain medical procedures or laboratory tests that do not have any scientific load, as well as provide consulting services, create intellectual property, the profits of which are usually have features of taxation.

In practice, there are cases of criminal prosecution for a set of criminal offenses belonging to the sphere of both official and economic activities [21].

\section{CONCLUSIONS}

The study demonstrates the need for a systematic approach to the settlement and enforcement of liability for violations related to clinical trials. In addition, the protection of public and private interests may be provided by other legal institutions, in particular, insurance, as well as compensation for property and moral damage. As for the insurance institute in the world practice, clinical trials mainly use the liability insurance of the research sponsor, while the Ukrainian legislation provides for life and health insurance of the subject of the study.

Particular attention needs to be paid to the standardization of criminal liability for offenses in this area, which are quite heterogeneous, and the correct legal qualification of certain actions requires knowledge of special legislation in the field of clinical trials, including international rules and ethics.

In addition, it is important to consider the legal nature of clinical trials that are outwardly similar to conventional medical practice, which they are not, as it differs in the purpose and nature of actions related to compliance with the trial protocol of an unregistered medicinal product to determine its effectiveness. and security. Clinical trials are scientific and innovative activities in the field of medicine, the essence of which is to study an unregistered medicine drug to establish (confirm) its effectiveness and safety. Therefore, causing harm during such tests must be carried out according to the rules of justified risk.

The diversity of violations that may be committed by different entities involved in the clinical trial makes it impossible to combine the relevant components of criminal offenses in a separate section of the legal act establishing criminal liability.

Resolving the issue of criminalization of certain offenses that may be committed by subjects involved in a clinical trial, it is advisable to consider their social danger and harm. Thus, it is controversial to introduce criminal liability for any violation of clinical trial order, regardless of its harmfulness.

When ensuring the protection of the rights and interests of research subjects and public interests in the field of health care, it is advisable to apply other types of legal liability (civil, administrative, disciplinary), taking into account the degree of harmfulness of the offenses under consideration.
When settling liability for a clinical trial in violation of the informed consent procedure, it should be considered that such consent may in some cases be given orally and not only by the subject or his/her legal representative, but also by close relatives.

\section{REFERENCES}

1. Clinical trials in human medicines Available from: https://www.ema. europa.eu/en/human-regulatory/research-development/clinicaltrials-human-medicines/[reviewed 2020.08.24].

2. Monitoring processes to R\&D. Published: March 2020. Available from: https://www.who.int/research-observatory/monitoring/processes/ clinical_trials_1/en/[reviewed 2020.08.21].

3. IntegrirovannoedopolneniekICHE6(R1):Rukovodstvo po nadlezhaschey klinicheskoy praktike E6(R2) [Integrated addendum to ICH E6 (R1): guideline on Good Clinical Practice E6 (R2)] of 09 November 2016, Available from: https://ichgcp.ru/ [reviewed 2020.08.24]

4. Posibnyk za statteiu 8 Konventsii pro zakhyst prav liudyny ta osnovopolozhnykh svobod Pravo na povahu do pryvatnoho i simeinoho zhyttia [Handbook under Article 8 of the Convention for the Protection of Human Rights and Fundamental Freedoms The right to respect for private and family life] Pereklad $z$ dopovnenniamy 0 . Drozdova ta 0 . Drozdovoi, sichen 2018 roku. Available from: https://unba.org.ua/assets/ uploads/1259d4263dac852ef056_file.pdf [reviewed 2020.08.21] (Ua).

5. Case of «A.M. and A.K. v. Hungary» Judgment of 4 April 2017. Available from: https://precedent.ua/1620051329 [reviewed 2020.08.21].

6. Nyurnbergskiy kodeks. Helsinskaya deklaratsiya [Nuremberg Code. Declaration of Helsinki], Available from: https://ulitka-kapusha. livejournal.com/51653.html [reviewed 2020.08.21] (Ru).

7. Strakhuvannia klinichnykh vyprobuvan likarskykh zasobiv v Ukraini (vidpovidalnosti zamovnyka na vypadok nanesennia shkody zhyttiu ta zdoroviu doslidzhuvanym: Metodychni rekomendatsii. [Insurance of clinical trials of medicines in Ukraine (liability of the customer in case of harm to life and health of the subjects): guidelines] Available from: http:// strahovoydom.com.ua/wp-content/uploads/2014/03/metodychni_ rekomendatsii_strakhuvannya.pdf/ [reviewed 2020.08.24] (Ua).

8. Regulation (EU) № 536/2014 of the Turopean Parliament and of the Council of 16 April 2014. Available from: http://pharmadvisor.ru/ documents/ss3680/ss3680.html [reviewed 2020.08.24].

9. Evropeyskaya hartiya prav patsientov [European Charter of Patients' Rights], [Online], Available from: http://health-rights.org/index.php/cop/item/ европейская-хартия-прав-пациентов-2 [reviewed 2020.08.24] (Ua).

10. Kryminalnyi kodeks Ukrainy [Criminal Code of Ukraine], the new version of the Law as of 22 November 2018 № 2617-VIII. Available from: https:// zakon.rada.gov.ua/laws/show/2341-14 [reviewed 2020.09.14].

11. Kodeks pro administratyvni pravoporushennia Ukrainy [Code of Administrative Offenses of Ukraine] vid 07 hrudnia 1984 roku № $8073-X$. Available from: https://zakon.rada.gov.ua/laws/show/80731-10\#Text [reviewed 2020.08.24] (Ua).

12. Osnovy zakonodavstva Ukrainy pro okhoronu zdorovia: Zakon Ukrainy [Principles of Ukrainian Health Care Legislation: Law of Ukraine] of 19 November 1992 № 2801-XII. Available from: https://zakon.rada.gov. ua/laws/show/2801-12 [reviewed 2020.08.24] (Ua).

13. Dutchak S.R. Zabezpechennia okhorony prav patsiientiv v Ukraini: kryminalno-pravovyi aspekt [Ensuring the protection of patients' rights in Ukraine: criminal law aspect]: dys. ... kand. yuryd. nauk : 12.00.08-kryminalne pravo ta kryminolohiia; kryminalno-vykonavche pravo. Kyiv. 2018.252 p. Available from: https://nam.kiev.ua/files/tesis/ dutchak_diss.pdf [reviewed 2020.08.24] (Ua). 
14. Kryminalnyi kodeks Respubliky Polshcha [Criminal Code of the Republic of Poland] pid red. Menchynskoho; per. z pol. V. S. Stanich. Kyiv: OVK, 2016. 138 p. [reviewed 2020.08.31] (Ua).

15. Kryminalnyi kodeks Ukrainy: naukovo-praktychnyi komentar: u 2-kht. [Criminal Code of Ukraine: scientific and practical commentary] za zah. red. V. Ya. Tatsiia, V. I. Borysova, V.I. Tiutiuhina. 5-te vyd., dopov. Kharkiv: Pravo, 2013. T. 1: Zahalna chastyna. 376 s. [reviewed 2020.08.31] (Ua).

16. Borysov V.I, Antoniuk 0.I., Vyshnyvetskyy I.I.Special features of the legal status of the research subject in clinical testing of medicines. Wiadomości Lekarskie. 2019. Tom LXXII., nr 12 cz. II: 2464-2471.

17. Babanly K. Ustanovlena uholovnaia otvetstvennost za falsyfykatsyiu LS, narushenye poriadka doklynycheskoho yzuchenyia, klynycheskykh yssledovanyi y hosudarstvennoi rehystratsyy LS. [Criminal liability has been established for counterfeiting medicines, violating the procedure for preclinical study, clinical studies and state registration of medicines] Available from: https://www.legalalliance.com.ua/rus/ publikacii/ustanovlena-ugolovnaa-otvetstvennost-za-falsifikaciu-lsnarusenie-poradka-dokliniceskogo-izucenia-kliniceskih-issledovaniji-gosudarstvennoj-registracii-Is/[reviewed 2020.08.24] (Ru).

18. EBA nadeetsia na rassmotrenye nardepamy voprosa otmeny uholovnoi otvetstvennosty v sfere klynyssledovanyi oseniu [EBA hopes for the people's deputies to consider the issue of canceling criminal liability in the field of clinical trials in the fall] 20 avhusta 2018 hoda. Available from:https://interfax.com.ua/news/pharmacy/525698.html [reviewed 2020.08.24] (Ru).

19. Shapran E. Uholovnaia otvetstvennost VS klynycheskye yspytanyia: kto koho? [Criminal liability VS clinical trials: who will win?] Available from: http://pharma.net.ua/publications/articles/23505-ugolovnajaotvetstvennost-vs-klinicheskie-ispytanija-kto-kogo/[reviewed 2020.08.24] (Ru).

20. Statystychna informatsiia pro zareiestrovani kryminalni pravoporushennia ta rezultaty yikh dosudovoho rozsliduvannia (za 2013-2019 r.r.). [Statistical information on registered criminal proceedings and the results of their pre-trial investigation 2013-2019] Heneralna prokuratura Ukrainy: veb-sait. Available from: https://www. gp.gov.ua/ua/1stat [reviewed 2020.31.08] (Ua).
21. Vyrok Kyievo-Sviatoshynskyi raionnyi sud Kyivskoi oblasti vid 08 liutoho 2013 roku. [Verdict of the Kyiv-Sviatoshynskyi District Court of the Kyiv Region of February 8, 2013] Available from: http://www.reyestr.court. gov.ua/Review/29231263 [reviewed 2020.31.08] (Ua).

\section{ORCID and contributionship:}

Viacheslav I. Borysov: 0000-0003-0291-9347 D, E, F

Olena I. Antoniuk: 0000-0003-1825-3981 A,B,D

Olexander O. Pashchenko: 0000-0001-9640-0137 B, D, E

\section{Conflict of interest:}

The Authors declare no conflict of interest.

\section{CORRESPONDING AUTHOR Vyacheslav I. Borisov}

Academician Stashis Scientific Research Institute for the Study of Crime Problems

National Academy of Law Sciences of Ukraine, Kharkiv, Ukraine, 49 Pushkinska str., Kharkiv 61002, Ukraine

tel: +380689886921

e-mail: borisov_v.i@ukr.net

Received: 29.08 .2020

Accepted: 30.11 .2020

A - Work concept and design, B - Data collection and analysis, C - Responsibility for statistical analysis, D - Writing the article, $\mathbf{E}$ - Critical review, $\mathbf{F}$ - Final approval of the article 